'Not guilty' verdict challenged Sydney

Four years after a Royal Commission adjudged that the widely used defoliant Agent Orange had caused no measurable or lasting ill-effects in soldiers in Vietnam, a group of Australian scientists has called the commission's findings unscientific. Eighteen biologists, chemists and immunologists from some of Australia's leading universities held a conference in Canberra last April under the title Evatt Revisited, in reference to the 1983 Royal Commission on the Use and Effects of Chemical Agents on Australian Personnel in Vietnam, headed by Justice Phillip Evatt. The proceedings of the conference were published last week, and include the charge that the commissioners simply duplicated large sections of the submission by Monsanto, the US chemical company that makes Agent Orange.

The Evatt Royal Commission was set up to determine whether Australian servicemen who served in Vietnam were more likely than others to suffer from cancer and whether their children had a higher probability of birth deformities. Since the commission released its findings in July 1985, it has been the target of complaints from the Vietnam Veterans Association of Australia (VVAA), from witnesses who testified before it and now from some of Australia's most senior scientists. Critics say, among other things, that the report is shallow and extravagantly worded, that scientific evidence was poorly interpreted and that VVAA witnesses were treated as "hostile".

TOXIC WASTE DISPOSAL

In 1987, the federal government ordered an inquiry into the findings of the Royal Commission, and concluded that the commission should not have come out with its "not guilty" assertion. The report maintained that the commission's findings and conclusions were sustainable but that it lacked credibility because of the manner in which the inquiry was conducted. But the new criticisms raised in Evatt Revisited are the first to complain about the commission's handling of the scientific evidence.

Ted Steele, a biologist from the University of Wollongong and one of the editors of Evatt Revisited, says that the commission's conclusions that exposure of civilians to Agent Orange had little or no effect on birth abnormalities was not warranted. He says that new evidence of birth abnormalities has come forward since the Royal Commission did its work, and believes that such findings "suggest that more cautious recommendations should have been forthcoming both from the Royal Commission and their scientific advisors". But Steele also has a more serious charge: he says that "large tracts of the report were plagiarized verbatim from the submission of Monsanto". But John Coombs QC, counsel assisting the commission, says Steele's allegation is "nonsense". He points out that it is common practice for a commission to incorporate appropriate parts of the submissions received into its report, and adds that "part of the VVAA submission was also reproduced".

Tania Ewing

\section{Commercial plans delayed} Cape Town

Plans by a Cape Town company, Peacock Bay Environment Services, to build a toxic-waste disposal plant that would process imported as well as domestic waste have been put on hold by Gert Kotze, South Africa's minister of the environment. Kotze announced last month that the government would not consider licensing the importation of toxic waste before it had been presented with the results of a newly commissioned survey on domestic waste disposal. The survey will be conducted by the CSIR's Foundation for Research Development.

According to Sidney Sanders, a director of the company, the importation of foreign waste is essential for the economic success of the proposed R400 million (\$160 million) development.

He also claims that the plant offers "the first viable alternative to the inadequate way in which toxins are being disposed of in this country". But unease over the plans derives more from worries over the transportation of waste than its treatment at the plant. A local toxic-waste transport company has indicated its reluctance to transport more waste by road, because the risk of accidents is too high, but Peacock Bay proposes to use the rail system instead.

The development, whose intended site is Alexander Bay, on the west coast 600 $\mathrm{km}$ north of Cape Town, is believed to be the first proposed under the new Environmental Conservation Act, promulgated by parliament in June of this year. The Act makes environmental impact assessment a legal prerequisite, and the Peacock Bay company says it has followed the procedures laid down by the act "to the letter", and has spent $\mathrm{R} 750,000(\$ 300,000)$ on an impact assessment study.

But local environment groups, spearheaded by the newly formed pressure group Earthlife Africa, have come out against the idea of importing toxic waste. Kotze, meanwhile, has accused Earthlife Africa of sowing suspicion about the government's integrity, but his department nonetheless appears to be sensitive to public reaction.
Michael Cherry

\section{FBI interference with} libraries criticized

\section{Washington}

FrEsh concerns arose last week over interference by the Federal Bureau of Investigation (FBI) in the operation of academic and other public libraries. A year ago, the FBI came under attack for its long-standing Library Awareness Program (LAP), in which it tried to enlist the help of librarians in identifying foreign spies who might be seeking access to scientific and technical libraries (see Nature 336, 507; 1988). Now documents obtained by the National Security Archive (NSA), a non-profit Washington library and research centre, reveal that librarians who refused to help the FBI or publicly criticized LAP were subsequently investigated to see if the campaign against LAP was itself part of a Soviet plot.

The NSA, whose collection includes a variety of unclassified and declassified government materials, requested documents concerning LAP under the Freedom of Information Act, and then filed a followup lawsuit when the FBI failed to deliver. Under an agreement reached earlier this year, the FBI has now released 1,200 pages of internal documentation, blacked out in some places.

The FBI memoranda reveal that activities under LAP were continued through the past two years despite assurances from senior officials to the American Library Association (ALA) that the programme was put in abeyance after December 1987. FBI agents were, however, told not to refer to LAP by name because of the adverse publicity. And one internal FBI communication, dated 6 February 1989, notes that although 266 individuals had been subjected to "indices checks" since November 1987 , only eight "references" were found. The purpose of these background checks, according to the FBI memo, was to "determine if a Soviet active measures campaign had been initiated to discredit the Library Awareness Program". The nature of the eight "references" turned up is not revealed.

But according to an FBI spokesman the ALA and the NSA are reading sinister motives into routine matters. Whenever anyone writes to the FBI on any subject, files are checked to see if the person has had any previous contact with the FBI, has been investigated by the bureau, has a criminal record, and so on. The "indices checks" referred to in the memo are simply searches through existing FBI files to see if a positive entry exists in any one of about 250 categories. The spokesman emphasized that these checks do not involve sending out agents to conduct personal investigations or questioning. Nevertheless, lawyers for the ALA are sifting through the 1,200 pages of FBI documents to see if there are any grounds for further action.

David Lindley 